\title{
Article \\ Psychometric Properties of the Emotional Exhaustion Scale (ECE) in Chilean Higher Education Students
}

\author{
Jonathan Martínez-Líbano ${ }^{1, *(\mathbb{C})}$, María-Mercedes Yeomans ${ }^{2,3, * \mathbb{C}}$ and Juan-Carlos Oyanedel ${ }^{1}$ (I) \\ 1 Facultad de Educación y Ciencias Sociales, Universidad Andrés Bello, Santiago 8370035, Chile; \\ juan.oyanedel@unab.cl \\ 2 Doctorado en Educación, Universidad Internacional Iberoamericana, Campeche 00613, Mexico \\ 3 Facultad de Educación, Universidad de Las Américas, Viña del Mar 2520000, Chile \\ * Correspondence: ps.jmartinez@gmail.com (J.M.-L.); mmyeomans@outlook.com (M.-M.Y.)
}

\section{check for}

updates

Citation: Martínez-Líbano, J.;

Yeomans, M.-M.; Oyanedel, J.-C.

Psychometric Properties of the Emotional Exhaustion Scale (ECE) in Chilean Higher Education Students. Eur. J. Investig. Health Psychol. Educ. 2022, 12, 50-60. https://doi.org/ 10.3390/ejihpe12010005

Academic Editors: África Martos Martínez and Ana Belén Barragán Martín

Received: 22 November 2021

Accepted: 4 January 2022

Published: 10 January 2022

Publisher's Note: MDPI stays neutral with regard to jurisdictional claims in published maps and institutional affiliations.

Copyright: (C) 2022 by the authors. Licensee MDPI, Basel, Switzerland. This article is an open access article distributed under the terms and conditions of the Creative Commons Attribution (CC BY) license (https:/ / creativecommons.org/licenses/by/ $4.0 /)$.

\begin{abstract}
The main objective of this study was to estimate the psychometric properties of the Emotional Fatigue Scale (ECE) in a sample of 1308 Chilean university students and confirm the unifactorial structure of the scale. Exploratory and confirmatory factor analyses were carried out. The ECE assessment had an internal consistency of 0.893 (Cronbach's Alpha). An exploratory factor analysis with Varimax rotation and a confirmatory analysis were performed, obtaining the factor that explains $52.3 \%$ of the variance. The results indicated that the ECE has adequate psychometric properties for use with higher education students in Chile. The ECE scale has good psychometric properties to be applied in the Chilean university context. Its usage may be very relevant to contribute to higher education institutions to emphasize students' mental health and prevent possible severe pathologies in future professionals. It is suggested to use the ECE scale together with the EES-Int, which is the only interpretation table for this instrument.
\end{abstract}

Keywords: emotional exhaustion; mental health; university students

\section{Introduction}

Emotional exhaustion is a major problem among students in higher education and a public health problem in general [1-6]. Higher education is a challenging context where students, particularly those with low resources, are susceptible to emotional exhaustion [3,7]. The impact of poverty on students' academic achievement is significant; students may face challenges with their cognitive and literary ability and often begin school academically and socioeconomically behind their peers from higher-income backgrounds [8]. Emotional exhaustion or burnout refers to the situation in which people feel that they can no longer give more of themselves on an affective level; it is a situation of depletion of one's energy or emotional resources [9]. In recent years, emotional exhaustion among adolescent and university students has acquired broader importance in national educational policy in many countries [10-15]. Moreover, emotional exhaustion develops from an acute to a chronic problem when faced with persistently stressful circumstances $[2-4,16]$. One example is the effects of a pandemic such as COVID-19 on the mental health of Chilean students [1,3,4]; $15 \%$ of Chilean university students had severe mental health problems [17], moderate depression has increased from $17.7 \%$ to $20.7 \%$, severe depression has increased by $5.2 \%$, severe anxiety has risen from $16.7 \%$ to $26.4 \%$, and severe stress has increased from $9.4 \%$ to $15.9 \%$ [18].

A student's level of burnout directly impacts that student's level of efficiency and productivity [11]. More than one-third of college students experience detrimental imbalances between the effort they put into their studies and the rewards they receive in return [19]. The consequences of emotional exhaustion in students are as complex as other factors of mental distress, such as those related to smoking and alcohol consumption or an unhealthy lifestyle [6]. Emotional exhaustion can also lead to depression [20] and anxiety [21], feelings 
of abandonment and Internet addiction, and compromised satisfaction with life in general, and success in educational pathways [22]. We can add practical consequences such as dropping out of school [19], potentially leading to sleep disorders, depression, and even suicidal thoughts and ideation in this age group [2,23]. Together with emotional exhaustion, drugs and alcohol consumption to reduce stress cause concern [24]. A student's performance can be seriously affected by the various emotional, behavioral, cognitive, and physiological reactions caused by burnout [11].

Several tests measure burnout or emotional exhaustion as a primary or secondary endpoint. The Maslach Burnout Inventory (MBI) instrument evaluates three areas: personal fulfillment at work (eight items), emotional exhaustion (nine items), and depersonalization (five items) [25-27]. On the other hand, the emotional exhaustion scale of the Copenhagen Psychosocial Questionnaire (CPQ) was developed by a consortium of health and wellbeing researchers in the workplace [28]. The scale consists of four Likert-scaled items where participants rate how they currently feel on a 5-point scale, whose estimated mean reliability was 0.77 [29]. Finally, the Emotional Fatigue Scale (ECE) is a specific scale that considers the last 12 months of student life; the items are inspired by the MBI emotional exhaustion scale and include Freudenberger's concept of burnout. To this base were added items specially designed to evaluate university students' fatigue or emotional exhaustion, which derived from the level of demand and effort to overcome their studies [30].

Although the MBI was validated for use in Chilean adults in 2005, its primary purpose is not to assess emotional exhaustion in university students [31]. On the other hand, the CPC focuses only on the work environment [28]. Emotional exhaustion needs to be investigated in depth since it is the most relevant burnout variable. It is, for some authors, the most obvious, complex, and the most widely reported and analyzed manifestation, which is associated with many psychological and psychiatric pathologies [32-36]. Concerning the university population, emotional exhaustion is one of the main concerns of the educational system [16]. Having a scale with good psychometric properties to be measured in the Chilean university context is very relevant [30] to contribute to higher education institutions' authorities to emphasize students' mental health and prevent possible severe pathologies in future professionals [1]. Therefore, this study aims to estimate the psychometric properties of the ECE in Chilean university students.

\section{Materials and Methods}

\subsection{Participants}

The sample was nonprobabilistic, composed of 1308 students from Chilean institutions of higher education, who met the following inclusion criteria, accepted the informed consent, and were studying in an institution of higher education. Inclusion criteria: University students and former students who graduated less than one year before the evaluation, Chilean, and enrolled in Chilean higher education institutions that had signed the informed consent. Exclusion criteria: All incomplete questionnaires were excluded. Concerning ages, the mean and standard deviation were $26.86 \pm 8.10$. The coefficient of variation (CV) was 35.30. The sample was nonprobabilistic, composed of 1308 students from Chilean institutions of higher education, aged between 17 and 69 years ( $\leq 17: 0.2 \%$; 18-20: 26.1\%; 21-29: 49.3\%; 30-39: $17.2 \%$; 40-49: 5\%; 50-59: 2.2\%; 60-69: 0.2\%). Concerning gender, $20.9 \%$ were male, and $79.1 \%$ were female. About majors, the sample consisted of health sciences $(33.4 \%)$, social sciences $(15.4 \%)$, natural sciences $(12.4 \%)$, education $(11.7 \%)$, business and administration $(9.3 \%)$, engineering and technology $(6 \%)$, communication $(5 \%)$, architecture and arts $(1 \%)$, and legal sciences (5.8\%). Regarding the academic progress of the students, $27.2 \%$ of them were in the first year, $23.3 \%$ in the second year, $21.6 \%$ in the third year, $16.7 \%$ in the fourth year, $8.1 \%$ in the fifth year, and $3.1 \%$ in the process of graduation.

\subsection{Instruments}

For this study, a questionnaire was elaborated, which was validated through expert judgment. The first section included demographic questions such as age, gender, and 
academic program. The second section included general questions regarding the perception of students' own mental health, such as: "Do I think my mental health has worsened?"; "At this time, I have presented symptoms of stress?"; and "At this time, I have presented depressive symptoms?". The third section consisted of the emotional exhaustion scale (ECE) (Appendix A) [30]. It is a specific scale that considers the last 12 months of students' lives. It was inspired by the MBI emotional exhaustion scale [37] and Freudenberger's concept of burnout. The ECE is a unidimensional scale of 10 items. The items are scored from 1 to 5 , depending on the occurrence of what the statement says: $1=$ rarely, $2=$ few times, $3=$ sometimes, $4=$ frequently, and $5=$ always. The score obtained on the ECE ranges from 10 to 50 points. Its level of internal consistency (an alpha coefficient of 0.893 ) and satisfactory item homogeneity (mean interitem correlation $=0.33$ ). The ECE results are interpreted by the Emotional Exhaustion Scale Interpretation Table (EES-Int) in the cognitive, emotional, and social-interactive dimensions [3]. The questionnaire applied electronically includes, as a first step, the signing of informed consent for data collection. The recollected data were demographic and anonymous. The study was conducted under the authorization of the Bioethics Committee of Universidad Andrés Bello, under resolution 90660/2020. The whole study was performed under the latest version of the Helsinki declaration.

\subsection{Data Analysis}

The data were analyzed with SPSS version 25 for Windows [38], $p$ value $\leq 0.001$. The instrument's reliability was estimated by calculating Cronbach's alpha internal consistency [39]. We calculated the corrected item correlation and the alpha coefficient for the ten items. An exploratory factor analysis was performed with the extraction of principal components and Varimax rotation. For the confirmatory factor analysis, SPSS AMOS was used [40]. We included the Kaiser-Meyer-Olkin sample adequacy measure (KMO) and Barlett's test of sphericity, measuring the approximate Chi-square (362.386), degree of freedom (df) (35), and significance $(p \leq 0.001)$ [41,42]. Regarding the factors, the discrepancy between the model and the actual data of the sample was measured through an Explained Variance analysis. Finally, we analyzed the absolute fit measures (Chi-square, RMSEA), incremental fit measures (CFI, TLI, IFI, NFI), and parsimony fit measures (PRATIO, PCFI, PNFI, AIC).

\section{Results}

\subsection{Instrument Reliability}

Cronbach's Alpha reliability analysis was performed for the entire scale to calculate the instrument's reliability. Table 1 shows the correlations between the items and the total score at 0.03 . The total reliability of the instrument is 0.893 , including all the items. In addition, reliability analysis was performed for each of the ten items (see Table 1).

Table 1. Corrected item correlation and Cronbach's alpha if the item is removed.

\begin{tabular}{ccc}
\hline Component & Corrected Item Correlation & Cronbach's Alpha If the Item Is Removed \\
\hline I & 0.641 & 0.882 \\
II & 0.518 & 0.892 \\
III & 0.553 & 0.888 \\
IV & 0.62 & 0.883 \\
V & 0.655 & 0.881 \\
VI & 0.656 & 0.881 \\
VII & 0.762 & 0.873 \\
VIII & 0.634 & 0.883 \\
IX & 0.659 & 0.881 \\
X & 0.699 & 0.878 \\
\hline
\end{tabular}




\subsection{Factor Analysis of the Scale}

An exploratory factor analysis was performed to estimate the validity of the ECE. As shown in Table 2, the KMO sample adequacy measure resulted in a value of 0.933 . Likewise, Bartlett's test of sphericity is significant $\left(x^{2}=5765.512097 ; p \leq 0.001\right)$. These results indicate that the necessary conditions are met to proceed with the factor analysis.

Table 2. Factor analysis application conditions.

\begin{tabular}{ccc}
\hline KMO & $\mathbf{0 . 9 3 3}$ \\
\hline & Approximate Chi-square & 5765.512097 \\
Sphericity Bartlett's test & df & 45 \\
& $p$-value & 0.000 \\
\hline
\end{tabular}

Df: degree of freedom; KMO: Kaiser-Meyer-Olkin measure; $p$-value: significance.

Table 3 shows the factors yielded by the principal component analysis, the percentage of the individual variance of each factor, and the percentage of accumulated variance. Consistent with Ramos et al., a single factor with an eigenvalue more significant than one is extracted [30]. Looking at Figure 1, which corresponds to the sedimentation plot, the previous result tends to be confirmed.

Table 3. Eigenvalues and percentage of variance explained by each factor.

\begin{tabular}{cccc}
\hline \multicolumn{3}{c}{ Initial Eigenvalues } \\
\hline Component & Total & Variance $\%$ & Accumulate $\%$ \\
\hline $\mathbf{1}$ & 5.200 & 52.003 & 52.003 \\
$\mathbf{2}$ & 0.878 & 8.777 & 60.780 \\
$\mathbf{3}$ & 0.754 & 7.537 & 68.317 \\
$\mathbf{4}$ & 0.577 & 5.765 & 74.082 \\
$\mathbf{5}$ & 0.537 & 5.370 & 79.452 \\
$\mathbf{6}$ & 0.486 & 4.863 & 84.315 \\
$\mathbf{7}$ & 0.453 & 4.533 & 88.848 \\
$\mathbf{8}$ & 0.416 & 4.159 & 93.008 \\
$\mathbf{9}$ & 0.372 & 3.718 & 96.726 \\
$\mathbf{1 0}$ & 0.327 & 3.274 & 100.000 \\
\hline
\end{tabular}

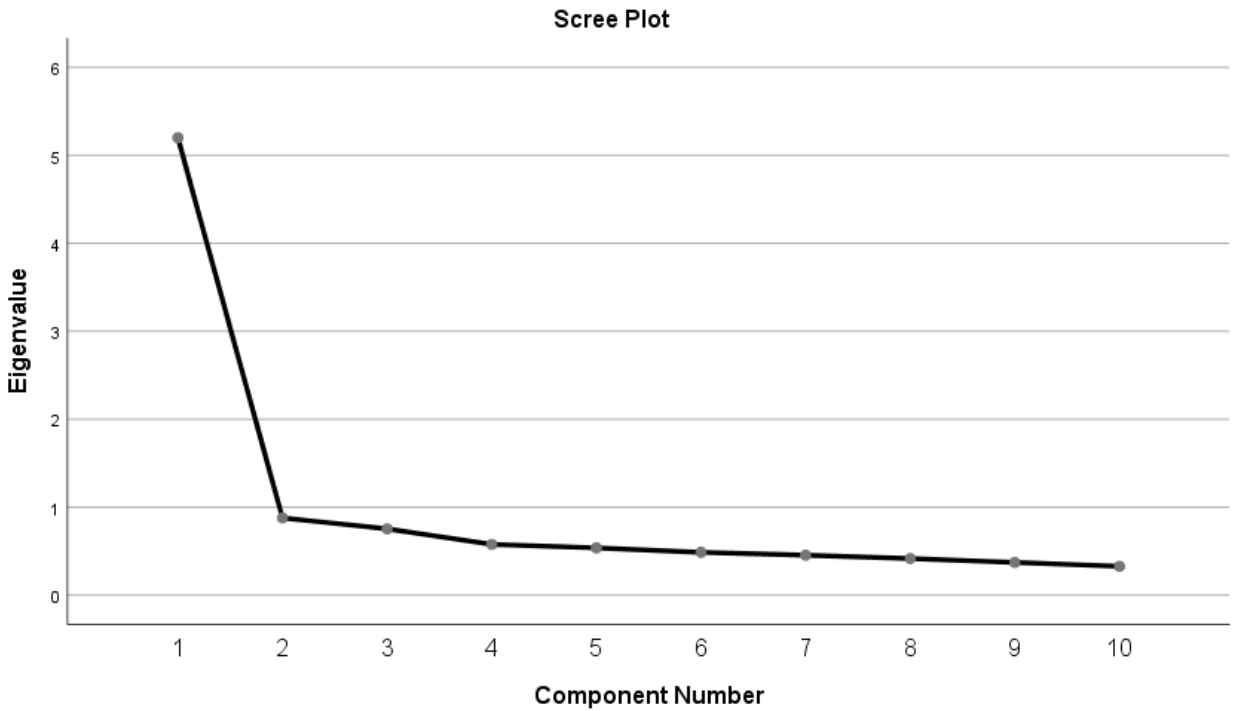

Figure 1. ECE Scree Plot. Considering that the results show a structure similar to previously reported validations $[30,43]$ and Cronbach's alpha results suggest that eliminating items would reduce its total value, the original scale structure was maintained. 


\subsection{Factorial Confirmatory Analysis}

In the analysis presented in Figure 2, all parameters were significant, and the indicators of the model presented fair values. Table 4 shows the goodness-of-fit results of the hypothetical model, which were sufficient to support the unifactorial structure of the scale. Positive results were identified in the CFI (0.943) and TLI (0.927), RMSEA values (0.85) and chi-square test $\left(\chi^{2}=362.386, p<0.000, \chi^{2} / g 1=10.354\right)$. Thus, the criteria required to accept an adequate value are met. All the indicators of the model (Table 4) showed fair values. The fit indexes showed acceptable values. The CFI is close to 0.95 showing a reasonable fit [44], whereas the RMSEA (0.85) presents an acceptable fit considering the sample size and model specification [45].

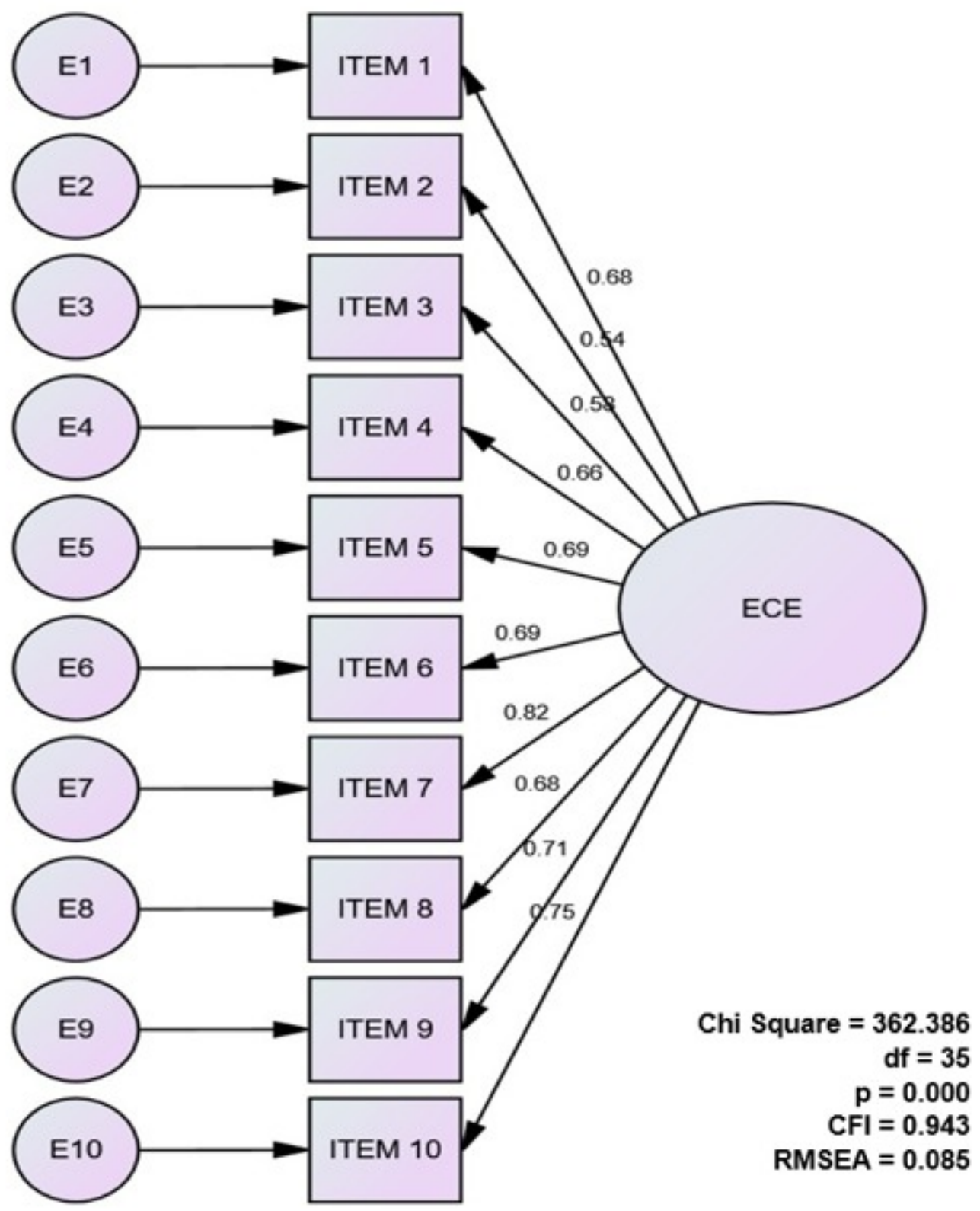

Figure 2. Confirmatory factor analysis graphic. 
Table 4. Confirmatory factor analysis goodness-of-fit indicators.

\begin{tabular}{ccc}
\hline Absolute Fit Measures & Chi-Square & 0 \\
\hline & RMSEA & 0.85 \\
\hline Incremental Fit Measures & CFI & 0.943 \\
\hline & TLI & 0.927 \\
& IFI & 0.943 \\
Parsimony Fit Measures & NFI & 0.937 \\
& PRATIO & 0.778 \\
& PCFI & 0.733 \\
& PNFI & 0.729 \\
& AIC & 422.386 \\
\hline
\end{tabular}

In Table 5, it is observed that the model meets the scalar invariance criterion. The means of the latent factors can be compared since there is a $\Delta \mathrm{CFI}<0.010$ and a $\Delta$ RMSEA $<0.015$ [45]

Table 5. Invariance models.

\begin{tabular}{ccccccc}
\hline Model & $\begin{array}{c}\chi^{2} \\
\mathbf{( g 1 )}\end{array}$ & CFI & $\begin{array}{c}\text { RMSEA } \\
{[\text { LCI-HCI] }}\end{array}$ & SRMR & $\Delta$ CFI & $\Delta$ RMSEA \\
\hline Configural & $\begin{array}{c}330.664^{* * *} \\
(68)\end{array}$ & 0.953 & $\begin{array}{c}0.054 \\
{[0.049-0.060]}\end{array}$ & 0.041 & & \\
\hline Metric & $\begin{array}{c}339.968^{* * *} \\
(77)\end{array}$ & 0.953 & $\begin{array}{c}0.051 \\
{[0.046-0.057]}\end{array}$ & 0.043 & 0.000 & -0.003 \\
\hline Scalar & $\begin{array}{c}366.677^{* * *} \\
(86)\end{array}$ & 0.949 & $\begin{array}{c}0.050 \\
{[0.045-0.055]}\end{array}$ & 0.043 & -0.004 & -0.001 \\
\hline Note. ${ }^{* * *} p<0.001$. & & &
\end{tabular}

\section{Discussion}

The main objective of this study was to estimate the psychometric properties of the Emotional Fatigue Scale (ECE) in a sample of 1308 Chilean university students and confirm the unifactorial structure of the scale. The original psychometric properties of the scale concerning internal consistency were a Cronbach's alpha of 0.83 and a unifactorial structure that explains $40 \%$ of the total variance. The instrument originated in Spain and was validated with students aged between 18 and 33 years [30]. When comparing our results with those reported by Ramos et al. (2005), we can observe that the variance explained in the exploratory factor analysis is higher than that reported by the authors of the ECE. In this study, the variance explained in the exploratory factor analysis was $52 \%$ and $94 \%$ in the confirmatory factor analysis. Our study's internal consistency $(\alpha=0.893)$ is slightly higher than the original $(\alpha=0.83)$. Although the goodness-of-fit indicators (Table 4 ) indicate that the model is susceptible to improvement, the percentage of variance explained suggests that working with a total ECE score is adequate. Thus, the unifactorial structure of the scale is confirmed. It can be said that the scale structure is maintained to allow comparative analysis from the above. Still, it is necessary to perform further studies to analyze factorial invariance.

This scale has been applied in different higher education students [3,46-49]. Moreover, there are many studies in mental health on the studied population [2-5]. Even though Chilean policies have been successfully adapting to emerging needs $[5,50]$, the scale has not been used until now in Chile, and we believe its validation will contribute towards that.

In our study, the Chilean validation maintains the psychometric structure for the instrument. The issue of the variance explained by the exploratory factor analysis (EFA) is diluted for two reasons: first, because only one factor has a high eigenvalue, meaning it does not make sense to increase the number of factors; despite integrating sensitivity to the instrument, it reduces its specificity $[51,52]$. On the other hand, when reviewing the 
Confirmatory Factor Analysis (CFA) data, it is possible to see a proper fit in its original version. Keeping the original version, which has acceptable psychometric properties, would allow the comparison between students from different countries [53]. This should be tested by employing invariance analysis in future studies [54].

The appropriate standardization of a given assessment instrument makes it possible to develop national norms for the valid interpretation of the meaning of a given person's scores on the standardized test [55]. Therefore, it is very relevant to study the adaptation of the scale for Chilean undergraduate students.

Concerning the Emotional Fatigue Scale (ECE), internal consistency in our sample of 1308 participants was 0.893 . Whether the reliability of a given assessment instrument is expressed in terms of an alpha coefficient, test-retest, interexaminer, or temporal reliability coefficient, it is helpful to develop guidelines for distinguishing clinically meaningful levels from those that may not be. Given the caveats regarding item ceiling and item floor effects and the need to consider alpha coefficients in the broader context of other types of reliability assessments (e.g., interexaminer), Cicchetti suggested guidelines. When the size of the alpha coefficient or other measure of internal consistency is below 0.70 , the level of clinical significance is unacceptable; when it is between 0.70 and 0.79 , the level of clinical significance is fair; when it is between 0.80 and 0.89 , the level of clinical significance is good; and when it is 0.90 and above, the level of clinical significance is excellent $[55,56]$. Based on the above, we can say that the Emotional Fatigue Scale (ECE) has a good level of clinical significance. The Cronbach's alpha of 0.893 found in our study is higher than that of other studies taken as a reference on the same subject (0.853 [57] 0.874 [58], 0.83 [59]).

This research confirms the principal component factor analysis, yielding a single factor with the ten items that make up the ECE. In this sense, the ECE scale has good psychometric behavior, presenting excellent evidence of factorial validity and good reliability indicators. The ECE is short, with only ten items, making easy to administer and score. In that case, it seems that the ECE scale is suitable for measuring emotional exhaustion in higher education students.

When comparing our study to the analysis of psychometric properties in Mexico [43], the latter was carried out with 506 psychology students from two universities. Exploratory and confirmatory factor analyses were performed, where an internal reliability of 0.90 was determined, confirming the unifactorial structure of the ECE and providing evidence of the validity of the scale.

Regarding the analysis of the psychometric properties of the ECE carried out in Peru [46], a similar sample of 448 psychology students from a private university was evaluated for reliability. Cronbach's alpha coefficient of 0.87 was adequate, proving the unifactoriality of the scale.

Although our study presents a more extensive and more diverse sample (1308 participants from different majors), we can still verify good internal reliability and a correct fit with a Cronbach's alpha coefficient of 0.893 , proving the unifactoriality of the scale.

Emotional exhaustion is a construct that should continue to be studied in the university context. In students, it has been correlated with anxiety, depression [60], stress [61,62], and some personality traits [30], which could affect the normative development of university students' lives.

In summary, the ECE has characteristics that make it very valuable for assessing emotional exhaustion in university students. It is a self-report instrument with excellent psychometric properties, aimed at a specific population such as higher education students. This instrument can help students, teachers, academics, and university authorities to detect and prevent possible psychological disorders in university students in their mental health.

Likewise, it is essential to develop an instrument to measure emotional exhaustion in teachers since it has been associated with their self-efficacy (as an enduring self-regulatory trait) [63], mood [16], stress [64], anxiety [65], and depression [60]. 
Keeping the original version of the ECE, which has acceptable psychometric properties, would allow the comparison between students from different countries, which should be tested by employing invariance analysis in future studies.

Although the study sample is large, it is not probabilistic. In future studies, the sample should be increased.

Concerning gender, the sample was not homogeneous between males and females ( $20.9 \%$ and $79.1 \%$, respectively); therefore, the studio may not represent the underrepresented gender.

Finally, the sample used was composed of university students, representing a very limited and special population considering their high level of education compared to the country population.

\section{Conclusions}

This study describes the psychometric properties of the emotional exhaustion scale (ECE) in a sample of Chilean university students. The properties of this version are good, and the results support the reliability and validity related to the construct of emotional exhaustion measured by the ECE. The ECE evaluation had an internal consistency of 0.893 . An exploratory factor analysis with Varimax rotation and a confirmatory analysis obtained a unifactorial model that explains $52.3 \%$ of the variance. The confirmatory factor analysis was $94 \%$. Therefore, the study of the results suggests that the emotional exhaustion scale has a good adequate psychometric property for higher education students in Chile. Consequently, the ECE is a reliable instrument to measure emotional exhaustion in Chilean university students. To better understand the mental health of Chilean university students, this instrument should be applied to other samples and correlated with other phenomena such as stress, anxiety, and depression.

The ECE scale has good psychometric properties to be applied in the Chilean university context. Its usage may be very relevant to contribute to higher education institutions to emphasize students' mental health and prevent possible severe pathologies in future professionals.

It is suggested to use the ECE scale together with the EES-Int [3], which is the only interpretation table for this instrument.

Author Contributions: Conceptualization, J.M.-L. and M.-M.Y.; methodology, J.M.-L. and M.-M.Y.; software, J.M.-L. and J.-C.O.; validation, J.M.-L. and J.-C.O.; formal analysis, J.M.-L. and M.-M.Y.; investigation, J.M.-L. and M.-M.Y.; resources, J.M.-L. and M.-M.Y.; data curation, J.M.-L.; writing-original draft preparation, J.M.-L.; writing —review and editing, M.-M.Y.; visualization, J.M.-L. and M.-M.Y.; supervision, M.-M.Y.; project administration, M.-M.Y.; funding acquisition, J.M.-L. and M.-M.Y. All authors have read and agreed to the published version of the manuscript.

Funding: This research received no external funding.

Institutional Review Board Statement: The study was conducted in accordance with the Declaration of Helsinki, and approved by the Bioethics Committee of Universidad Andrés Bello, under resolution $90660 / 2020$.

Informed Consent Statement: The questionnaire applied electronically includes, as a first step, the signing of informed consent for data collection. The recollected data were demographic and anonymous.

Data Availability Statement: Data sets analyzed or generated during the study are available for sharing if needed.

Conflicts of Interest: The authors declare no conflict of interest.

\section{Appendix A}

EMOTIONAL EXHAUSTION SCALE (RAMOS, 2005)

Below you will find a series of questions that refer to your way of thinking, feeling, and acting concerning your studies. Read each sentence and answer according to the 
last 12 months of your student's life by marking with an $\mathrm{X}$ according to the following rating scale:

Tests or evaluations cause me excessive stress.

I think I try too hard for the little I get out of it.

I feel down in the dumps, kind of sad, for no apparent reason.

There are days when I don't sleep well because of studying.

I have headaches and other discomforts that affect my performance.

There are days when I feel more exhausted, and I lack the energy to concentrate.

I feel emotionally drained by my studies.

I feel tired at the end of the day.

Working and/or studying with evaluations in mind causes me stress.

I lack time, and I feel overwhelmed by my studies.

\section{References}

1. Martínez-Líbano, J. Salud mental en estudiantes chilenos durante confinamiento por Covid-19: Revisión bibliográfica. Revista Educación Américas. 2020, 10, 265-276. [CrossRef]

2. Martínez-Líbano, J.; Yeomans, M.M. Suicidal ideation and suicidal thoughts in university students during the covid-19 pandemic: A systematic review. Rev. Argent. Clín. Psicol. 2021, 30, 390-405.

3. Yeomans, M.M.; Martínez-Libano, J.; Silva, A. Emotional Exhaustion in Chilean Higher Education Students during the Pandemic: Analysis by Gender. Psychol. Educ. 2021. Available online: https://www.researchgate.net/publication/356194062_Emotional_ exhaustion_in_Chilean_higher_education_students_during_the_pandemic_analysis_by_gender?channel=doi\&linkId=619186 f0d7d1af224bef6a8e\&showFulltext=true (accessed on 3 January 2022).

4. Martínez-Líbano, J.; Yeomans, M.M. González Campusano, N. Campos Flores, E. Emotional Exhaustion and Mental Health in a Sample of Chilean Social Science Students During the COVID-19 Pandemic. Period. Semest. 2021, 7, 69-81. Available online: https: //publicaciones.sociales.uba.ar/index.php/psicologiasocial/article/download/7149/6160 (accessed on 30 December 2021).

5. Yeomans, M.M.; Silva, A. Pedagogical and Psychosocial Implications of Quarantine by Covid-19 on Chilean Students. Rev. Educ. Las Américas 2020, 10, 100-108.

6. Tlili, M.A.; Aouicha, W.; Sahli, J.; Testouri, A.; Hamoudi, M.; Mtiraoui, A.; Ben Dhiab, M.; Chelbi, S.; Ajmi, T.; Ben Rejeb, M.; et al. Prevalence of Burnout among Health Sciences Students and Determination of Its Associated Factors. Psychol. Health Med. 2020, 26, 212-220. Available online: https:// pubmed.ncbi.nlm.nih.gov/32835517/ (accessed on 3 January 2022). [CrossRef]

7. Turhan, D.; Scheunemann, A.; Schnettler, T.; Bäulke, L.; Thies, D.O.; Dresel, M.; Fries, S.; Leutner, D.; Wirth, J.; Grunschel, C. Psychometric Properties of the German Short Version of the Maslach Burnout Inventory-Student Survey. Eur. J. Health Psychol. 2021, 28, 45-58. Available online: https:/ / psycnet.apa.org/record/2021-21161-001 (accessed on 3 January 2022). [CrossRef]

8. Taylor, K. Poverty's Long-Lasting Effects on Students' Education and Success. Insight Divers. 2017, 89, 30-32. Available online: https:/ / www.insightintodiversity.com/povertys-long-lasting-effects-on-students-education-and-success / (accessed on 18 December 2021).

9. Marrau, M. El Síndrome de Burnout y sus Posibles Consecuencias en el Trabajador Docente. Fundam. Humanid. 2004, 10, 53-68. Available online: https:/ / www.redalyc.org/pdf/184/18401004.pdf (accessed on 3 January 2022).

10. Allen, K.-A.; Reupert, A.; Oades, L. Building Better Schools with Evidence-Based Policy Building Better Schools with Evidence-Based Policy: Adaptable Policy for Teachers and Schools Leaders; Routledge: London, UK, 2021; Available online: https:/ /apo.org.au/sites/ default / files / resource-files/2021-04/apo-nid312303.pdf (accessed on 11 December 2021).

11. Galbraith, C.S.; Merrill, G.B. Academic performance and burnout: An efficient frontier analysis of resource use efficiency among employed university students. J. Furth. High. Educ. 2015, 39, 255-277. [CrossRef]

12. Ministerio de Educación Chile. Prevención del Suicidio Adolescente. 2021. Available online: https://formacionintegral.mineduc. cl/wp-content/uploads/2021/03/PrevencionSuicidioAdolescente.pdf (accessed on 11 December 2021).

13. Ministerio de Salud Chile. Recomendaciones para la Prevención de la Conducta Suicida en Establecimientos Educacionales. 2019. Available online: https://www.minsal.cl/wp-content/uploads/2019/03/GUIA-PREVENCION-SUICIDIO-ENESTABLECIMIENTOS-EDUCACIONALES-web.pdf (accessed on 11 December 2021).

14. Ministerio de Salud Chile. Guía de Prevención del Suicidio en Tiempos de COVID-19. 2020. Available online: https://www. minsal.cl/wp-content/uploads/2020/09/20200910_Gu\%C3\%ADaPrevSuicidioCOVID-19.pdf (accessed on 11 December 2021).

15. Ministerio de Salud Chile. Herramientas de Apoyo para la Prevención del Suicidio Guía Para. 2021. Available online: https: //www.minsal.cl/wp-content/uploads/2021/09/Herramientas_SaludMental_Sept2021.pdf (accessed on 11 December 2021).

16. Dicke, T.; Parker, P.D.; Guo, J.; Basarkod, G.; Marsh, H.W.; Deady, M.; Riley, P. Ubiquitous Emotional Exhaustion in School Principals: Stable Trait, Enduring Autoregressive Trend, or Occasion-Specific State? J. Educ. Psychol. 2021. [CrossRef]

17. Antúnez, Z.; Vinet, E.V. Mental health problems among students of a regional Chilean university. Revista Médica Chile 2013, 141, 209-216. [CrossRef] 
18. Álamo, C.; Antúnez, Z.; Baader, T.; Kendall, J.; Barrientos, M.; Barra, D.D.L. The sustained increase of mental health symptoms in Chilean university students over three years. Rev. Latinoam. Psicol. 2020, 52, 71-80. [CrossRef]

19. Williams, C.J.; Dziurawiec, S.; Heritage, B. More pain than gain: Effort-reward imbalance, burnout, and withdrawal intentions within a university student population. J. Educ. Psychol. 2018, 110, 378-394. [CrossRef]

20. Al-Alawi, M.; Al-Sinawi, H.; Al-Qubtan, A.; Al-Lawati, J.; Al-Habsi, A.; Al-Shuraiqi, M.; Panchatcharam, S.M. Prevalence and determinats of burnout Syndrome and Depression among medicar students at Sultan Qaboos University: A cross sectional analytical study form Oman. Arch. Environ. Occup. Health 2019, 74, 130-139. [CrossRef]

21. Farrell, S.M.; Molodynski, A.; Cohen, D.; Grant, A.J.; Rees, S.; Wullshleger, A.; Lewis, T.; Kadhum, M. Wellbeing and burnout among medical students in Wales. Int. Rev. Psychiatry 2019, 31, 613-618. [CrossRef] [PubMed]

22. Salmela-aro, K. Dark and bright sides of thriving-School burnout and engagement in the Finnish context. Eur. J. Dev. Psychol. 2017, 14, 337-349. [CrossRef]

23. Pagnin, D.; de Queiroz, V.; Amaral, M.; Filho, D.O. Burnout and career choice motivation in medical students. Med. Teach. 2013, 35, 388-394. [CrossRef]

24. Erschens, R.; Loda, T.; Herrmann-Werner, A.; Keifenheim, K.E.; Stuber, F.; Nikendei, C.; Zipfel, S.; Junne, F. Behaviour-based functional and dysfunctional strategies of medical students to cope with burnout. Med Educ. Online 2018, 23, 1535738. [CrossRef]

25. Maslach, C. Burnout: A Multidimensional Perspective. In: Professional Burnout. 2018. Available online: https://psycnet.apa. org/record/1993-97794-002 (accessed on 3 January 2022).

26. Maslach, C.; Leiter, M.P.; Schaufeli, W. Measuring Burnout. In The Oxford Handbook of Organizational Well Being; Oxford University Press: New York, NY, USA, 2009.

27. Maslach, C.; Schaufeli, W.B.; Leiter, M.P. Job Burnout. Annu. Rev. Psychol. 2001, 52, 397-422. [CrossRef]

28. Kristensen, T.S.; Hannerz, H.; Høgh, A.; Borg, V. The Copenhagen Psychosocial Questionnaire-A tool for the assessment and improvement of the psychosocial work environment. Scand. J. Work. Environ. Health 2005, 31, 438-449. [CrossRef] [PubMed]

29. Diefendorff, J.M.; Gabriel, A.S.; Nolan, M.T.; Yang, J. Emotion regulation in the context of customer mistreatment and felt affect: An event-based profile approach. J. Appl. Psychol. 2019, 104, 965-983. [CrossRef] [PubMed]

30. Ramos, F.; Manga, D.; Moran, C. Escala de Cansancio Emocional (ECE) para estudiantes universitarios: Propiedades psicométricas y asociación. Anales Psicol. 2005, 23, 253-257.

31. Buzzetti Bravo, M. Validación del Maslach Burnout Inventory (MBI), en dirigentes del colegio de profesores A.G. de Chile. Ph.D. Thesis, Universidad de Chile, Facultad de Ciencias Sociales Carrera de Psicología, Nuñoa, Chile, 2005. Available online: https:/ / repositorio.uchile.cl/handle/2250/137677 (accessed on 12 November 2021).

32. Da Silva, A.T.C.; Menezes, P. Burnout syndrome and common mental disorders among community-based health agents. Revista Saúde Pública 2008, 42, 921-929. [PubMed]

33. Pogere, E.F.; López-Sangil, M.C.; García-Señorán, M.; González, A. Teachers' job stressors and coping strategies: Their structural relationships with emotional exhaustion and autonomy support. Teach. Teach. Educ. 2019, 85, 269-280. [CrossRef]

34. Khorshidian, N.; Hashemian, S.; Meftagh, S.; Najimi, A. Burnout among the employees of health and therapy entities: Investigating the role of early maladaptive schemas and mental disorder symptoms. Anadolu Psikiyatr. Derg. 2017, 18, 323-329. [CrossRef]

35. Trigueros, R.; Navarro, N.; Cangas, A.J.; Mercader, I.; Aguilar-Parra, J.M.; González-Santos, J.; González-Bernal, J.; Soto-Cámara, R. The Protective Role of Emotional Intelligence in Self-Stigma and Emotional Exhaustion of Family Members of People with Mental Disorders. Sustainability 2020, 12, 4862. [CrossRef]

36. Tuithof, M.; Have, M.T.; Beekman, A.; van Dorsselaer, S.; Kleinjan, M.; Schaufeli, W.; de Graaf, R. The interplay between emotional exhaustion, common mental disorders, functioning and health care use in the working population. J. Psychosom. Res. 2017, 100, 8-14. [CrossRef] [PubMed]

37. Maslach, C.; Jackson, S.; Schwab, R. Maslach burnout inventory-educators survey (MBI-ES). In MBI Manual, 3rd ed.; MBI: Hong Kong, China, 1996.

38. IBM. IBM SPSS Statistics Software for Windows; Version 25; IBM: Armonk, NY, USA, 2017.

39. Rodríguez-Rodríguez, J.; Reguant-Álvarez, M. Calcular la fiabilidad de un cuestionario o escala mediante el SPSS: El coeficiente alfa de Cronbach. Rev. Innovaci Recer. Educ. 2020, 13, 1-13. [CrossRef]

40. Arbuckle, J.L. IBM SPSS Amos 23.0 User's Guide; IBM: Armonk, NY, USA, 2014. [CrossRef]

41. IBM. Kaiser-Meyer-Olkin Measure for Identity Correlation Matrix. 2021. Available online: https://www.ibm.com/support/ pages/kaiser-meyer-olkin-measure-identity-correlation-matrix (accessed on 12 November 2021).

42. Lloret-Segura, S.; Ferreres-Traver, A.; Hernández-Baeza, A.; Tomás-Marco, I. Exploratory Item Factor Analysis: A Practical Guide Revised and Updated. Anales de Psicol. 2014, 30, 1151-1169. Available online: https:/ /www.researchgate.net/publication/263139 570_Exploratory_Item_Factor_Analysis_a_practical_guide_revised_and_updated (accessed on 3 January 2022).

43. Teresa Gonzlez Ramírez, M.; Landero Hernández, R. Escala de Cansancio Emocional (ECE) Para Estudiantes Universitarios: Propiedades Psicométricas en una Muestra de México. Anales de Psicol. 2007, 23, $253-257$. Available online: https://www.semanticscholar.org/paper/Escala-de-cansancio-emocional-(ECE)-para-en-una-de-Ram\%C3\%ADrezHernandez/802d65260f894af43db81f901d98ac26fd3e263d (accessed on 3 January 2022).

44. Hu, L.-T.; Bentler, P.M. Cutoff criteria for fit indexes in covariance structure analysis: Conventional criteria versus new alternatives. Struct. Equ. Model. Multidiscip. J. 1999, 6, 1-55. [CrossRef] 
45. Chen, F.; Curran, P.J.; Bollen, K.A.; Kirby, J.; Paxton, P. An Empirical Evaluation of the Use of Fixed Cutoff Points in RMSEA Test Statistic in Structural Equation Models. Sociol. Methods Res. 2008, 36, 462-494. [CrossRef]

46. Burga Dávila, K.R.; Tuesta Campos, E.M. Evidencias Psicométricas de la Escala de Cansancio Emocional (ECE) en Estudiantes Universitarios de Ingeniería de una Universidad Estatal de Lima Metropolitana. Ph.D. Thesis, Universidad César Vallejo, Lima, Peru, 2021. Available online: https:/ / repositorio.ucv.edu.pe/bitstream/handle/20.500.12692/71215/Burga_DKR-Tuesta_CEMSD.pdf? sequence $=1 \&$ is Allowed $=y$ (accessed on 19 December 2021).

47. Carranza Esteban, R.F. Cansancio Emocional y Engagement Académico en Estudiantes Universitarios de Lima Metropolitana [Lima]. 2020. Available online: https://repositorio.usil.edu.pe/server/api/core/bitstreams/d48de02e-fd9c-45f1-b555-5828e1 f27ff3/ content (accessed on 19 December 2021).

48. Carreres, A.L.; González, T.M.P.; Torres, L.H.; Lledó, G.L. Cansancio Emocional, Autoestima Y Satisfacción Con Los Estudios En Estudiantes Universitarios. Int. J. Dev. Educ. Psychol. 2017, 7, 161-170. [CrossRef]

49. Estrada, N.T.; Sur, S.d.O.d.H.M.; Rosas, M.D.P.S. Inteligencia Emocional de los Estudiantes de Pregrado de las Licenciaturas de Enfermería. Revista Cuidarte 2020, 11, e993. Available online: https:/ / revistas.udes.edu.co/cuidarte/article/view/993 (accessed on 19 December 2021).

50. Yeomans, M.M. Evolution of Educational Administration in Chile and Professionalizing School Administration. Rev. Educ. 2020, 46. Available online: https://www.redalyc.org/journal/440/44068165002/44068165002.pdf (accessed on 11 December 2021).

51. Oyanedel, J.C.; Vargas, S.; Mella, C.; Páez, C. Los Autores Aludidos Ofrecieron la Siguienteréplica: Cálculo de Confiabilidad a Través del Usodel Coeficiente Omega de McDonald. Revista Médica de Chile 2017, 145, 272-273. Available online: https:/ / www. scielo.cl/scielo.php?script=sci_arttext\&pid=S0034-98872017000200019\&lng=en\&nrm=iso\&tlng=en (accessed on 11 December 2021). [CrossRef] [PubMed]

52. Rica, R.; Solar, M.; Compte, E.J.; Sepúlveda, A.R. Establishing the Optimal Male Cut-Off Point: Confirmatory Factor Analysis of the Eating Disorder Examination-Questionnaire (EDE-Q) in a Representative Sample of Spanish University Students. Eat. Weight. Disord. Stud. Anorexia Bulim. Obes. 2021, 1-9. Available online: https://pubmed.ncbi.nlm.nih.gov/34089512/ (accessed on 3 January 2022).

53. Azman, N.; Thien, L.M.; Abdullah, M.F.I.L.; Shariff, N.M. Psychometric Properties of the 34-Item Short-Form Supportive Care Need Survey (SCNS-SF34) Scale in the Malaysian Cancer Healthcare Context. Int. J. Environ. Res. Public Health 2021, 18, 9403. [CrossRef] [PubMed]

54. Espejo, B.; Checa, I.; Perales-Puchalt, J.; Lisón, J.F. Validation and Measurement Invariance of the Scale of Positive and Negative Experience (SPANE) in a Spanish General Sample. Int. J. Environ. Res. Public Health 2020, 17, 8359. [CrossRef]

55. Cicchetti, D.V. Guidelines, criteria, and rules of thumb for evaluating normed and standardized assessment instruments in psychology. Psychol. Assess. 1994, 6, 284-290. [CrossRef]

56. Chenani, K.T.; Madadizadeh, F. Guideline for Selecting Types of Reliability and Suitable Intra-class Correlation Coefficients in Clinical Research. J. Biostat. Epidemiol. 2021, 7, 305-309. [CrossRef]

57. Dominguez-Lara, S.; Calderon-De La Cruz, G.; Alarcon-Parco, D.; Navarro-Loli, J. Relation between State-Test Anxiety and Exam Performance in College Students: Preliminary Analysis of the Difference as per Course. Rev. Digit. De Investig. En Docencia Universitaria. 2017, 11, 166-176. [CrossRef]

58. Herrera Torres, L.; Mohamed Mohand, L.; Espinosa, S.C. Cansancio Emocional en estudiantes universitarios. Revista de Educação e Humanidades 2016, 9, 173-191.

59. Cortés, K. Cansancio Emocional en Personas que Trabajan y Estudian en la Ciudad de Bucaramanga. Ph.D. Thesis, Universidad Autonoma de Bucaramanga, Bucaramanga, Colombia, 2016. Available online: https://repository.unab.edu.co/handle/20.500.127 49/12262. (accessed on 3 January 2022).

60. Schonfeld, I.S.; Verkuilen, J.; Bianchi, R. An exploratory structural equation modeling bi-factor analytic approach to uncovering what burnout, depression, and anxiety scales measure. Psychol. Assess. 2019, 31, 1073-1079. [CrossRef] [PubMed]

61. Fukui, S.; Salyers, M.P.; Morse, G.; Rollins, A.L. Factors that affect quality of care among mental health providers: Focusing on job stress and resources. Psychiatr. Rehabil. J. 2021, 44, 204-221. [CrossRef]

62. Marcatto, F.; di Blas, L.; Luis, O.; Festa, S.; Ferrante, D. The Perceived Occupational Stress Scale: A Brief Tool for Measuring Workers' Perceptions of Stress at Work. Eur. J. Psychol. Assess 2021. Available online: https://psycnet.apa.org/record/2021-75876 -001 (accessed on 3 January 2022).

63. Soncini, A.; Politi, E.; Matteucci, M.C. Teachers Navigating Distance Learning During COVID-19 without Feeling Emotionally Exhausted: The Protective Role of Self-Ef fi cacy. Sch. Psychol. 2021, 36, 494-503. [CrossRef] [PubMed]

64. Horan, S.; Flaxman, P.E.; Stride, C.B. The perfect recovery? Interactive influence of perfectionism and spillover work tasks on changes in exhaustion and mood around a vacation. J. Occup. Health Psychol. 2021, 26, 86-107. [CrossRef]

65. Post, P.B.; Grybush, A.L.; Elmadani, A.; Lockhart, C.E. Fostering resilience in classrooms through child-teacher relationship training. Int. J. Play. Ther. 2020, 29, 9-19. [CrossRef] 